\title{
Pengaruh Faktor Internal dan Ekternal Terhadap Harga Saham
}

\author{
Elvin Ruswanda Yudistira*, I Made Pradana Adiputra \\ Universitas Pendidikan Ganesha, Singaraja, Bali, Indonesia \\ *elvin.ruswanda.yudistira@undiksha.ac.id
}

\author{
Riwayat Artikel: \\ Tanggal diajukan: \\ 25 Juni 2020 \\ Tanggal diterima: \\ 28 Agustus 2020 \\ Tanggal dipublikasi: \\ 31 Agustus 2020
}

Kata kunci: Faktor Internal, Faktor Eksternal, Harga Saham

\section{Pengutipan:}

Yudistira, E. R., \& Adiputra, I. M. P. (2020). Pengaruh Faktor Internal dan Ekternal Terhadap Harga Saham. Jurnal Ilmiah Akuntansi dan Humanika, 10(2), 176-184

Keywords: Internal Factor, External Factor, Stock Price

\begin{abstract}
Abstrak
Tujuan dari percobaan ini adalh untuk sanggup membuktikan pengaruh faktor internal dan faktor ekternal trhadap harga saham. Faktor internal antara lain: Return on Assets, Return on Equity, Net Interest Margin dan Biaya Operasi/Pensanggupan Operasional. Sedangkan faktor eksternal antara lain: Tingkat Inflasi dan BI Rate. Populasi pada riset ini adalh perseoran yg tercatat pada Bursa Efek Indonesia (BEI) sub sektor perbankan periode 2015-2019. Representatif pada riset ini sebanyak 32 perseoran dan menggunakan teknik pemungutan yaitu purposive sampling. Hasil akhir pada riset ini menunjukan bahwa secara parsial ROA berpengaruh positif dan signifikan trhadap harga saham. ROE berpengaruh negatif dan singifikan trhadap harga saham. NIM berpengaruh negatif dan tak signifikan trhadap harga saham. BOPO berpengaruh negatif dan tak signifikan trhadap harga saham. Tingkat Inflasi berpengaruh negatif dan tak signifikan trhadap harga saham. BI Rate berpengaruh positif dan tak signifikan trhadap harga saham. Secara simultan ROA, ROE, NIM, BOPO, Tingkat Inflasi dan BI Rate berpengaruh secara signifikan trhadap harga saham.
\end{abstract}

\begin{abstract}
The purpose of this experiment is to prove internal factors and external factors to the stock price. Internal factors include: Return on Assets, Return on Equity, Net Interest Margin and Operating Costs / Operational Scoping. While external factors include: the inflation rate and the $B I$ rate. The population in this study is the company placed on the Indonesia Stock Exchange (IDX) in the banking sector for the 2015-2019 period. There were 32 people represented in this study and used a collection technique, namely purposive sampling. The final results in this study indicate that $R O A$ has a positive and significant effect on stock prices. ROE is negative and significant towards stock prices. Negative shares and insignificant stock prices. BOPO negative and insignificant influence on stock prices. The inflation rate is negative and insignificant towards stock prices. BI Rate has a positive and insignificant effect on stock prices. Simultaneously ROA, ROE, NIM, BOPO, Inflation Rate and BI Rate significantly influence stock prices.
\end{abstract}

\section{Pendahuluan}

Dalam kesibukan sehari-hari, bank merupaakan salah satu institusi keuangan yg sering kita kenal, bank memiliki kegiatan utama seperti menetima simpanan tabungan, deposito, giro, dan lain-lain. Disamping itu, bank juga merupaakan tempat dimana masyarakat sanggup meminjam uang bagi yg membutuhkan modal usaha. Selain tempat menerima simpanan tabungan, deposito, giro, tempat meminjam uang, bank sanggup digunakan seb'agai te'mpat untu'k menukarkan mata uang, mmindahkan ung ke suatu tempat maupun mnerima segala macam bentuk pembayaran sperti contoh pembayaran bea cukai, 
pembayaran SPP kuliah, pembayaran elektrik, pembayaran air, pembayaran telepon (Kasmir, 2012)

Undang-Undang Republik Indonesia Nomor 10 tahun 1998 menyatakan bahwa Bank adalh badan usaha yg menghimpun dana dari masyarakat dalam bentuk simpanan dan menyalurkannya kepada masyarakat dalam bentuk kredit dan atau bentuk-bentuk lainnya dalam rangka menignkatkan taraf hidup rakyat banyak. Apabila diartikan secara luas, maka bank mrupakan suatu emiten yg bergerak dalam bidang keuangan, dalam kata lain aktivitas dari emiten ini selalu berkaitan dengan keuangan (Kasmir, 2012).

Perbankan di Indonesia mengalami progres yg sangat deras dari warsa ke warsa, sehingga antar perseoran menimbulkan persaingan yg ketat. Persaingan ini menuntut perseoran untuk menciptakan sebuah inovasi dan mengembangkan suatu konsep baru ke dalam perseoran, dan pada akhirnya nilai perseoran yg tercermin pada LK akan melambung. LK yg diumumkan ke pada publik setiap satu periode keuangan (Sujarweni, 2017)

Menghadapi persaingan yg ketat ini, salah satu cara yg sanggup dijalankan untuk mempengaruhi LK perseroan adalh dengan cara melakukan Go Public atau Initial Public Offering (IPO), dimana ketika perseoran melakukan IPO perseoran trsebut membuka da menawarkan sahamnya kepada publik di pasar modal (Kewal, 2013).

Harga saham di sub sektor perbankan yg tercatat di Bursa Efek Indone'sia mengalami pergerakan harga saham yg fluktuatif. Dimana harga saham di pasar modal Indonesia dipengaruhi oleh faktor eksternal dan faktor internal perseoran. Faktor-faktor eksternal antara lain kondisi perekonomian, politik, perbahan suku bunga, inflasi, kurs valuta asing, regulasi dan deregulasi perdagangan oleh negara. Selain faktor eksternal yg telah disebutkan, adapun aspek-aspek internal yg sanggup mempengaruhi perubahan harga saham antara lain perubahan harga suatu produk, penarikan produk baru, pendanaan pada perseoran, pergantian manajer perseoran, melakukan merger, melakukan ekspansi pabrik, pemgokan tenaga krja, serta penugumuman sutau LK perseoran (Alwi, 2003).

Faktor-faktor ekternal yg digunaakan dalam eksperimen ini adalh tingkat inflasi da'n BI Rate. Tingkat Inflasi merupaakan melambungnya price secara global dan terus-menerus dalam jangka tempo tertentu yg diebabkan oleh beberapa efek (Website Bank Indonesia, n.d.). Harga saham sanggup dipengaruhi oleh tinggi rendahnya tingkat inflasi, jika kondisi inflasi di Indonseia rendahi, maka akan menciptakan harga produk dalam negeri menjadi murah sehingga usaha beli massyarakat akan melambung. Hal trsebut akan menyebabkan penurunan jumlah uang yg beredar, sehingga kondisi ini membuat investor beralih ke pasar saham dibandingkan ke deposito.

Selain tingkat inflasi sebagai faktor eksternal yg mempengaruhi harga saham, tersanggup fak'tor eksternal lain yg digunakan dalam riset ini, yaitu $\mathrm{BI}$ Rate. BI Rate sering diperhitungkan sebagai faktor yg menentukan harga saham. Dari sisi permintaan, sebagian besar pakar dan praktisi pasar modal sepakat bahwa tersanggup hubungan asimetris antara suku bunga dan harga saham tak bisa dipungkiri (Tandelilin, 2007).

Selain faktor-faktor eksternal, tersanggup juga aspek internal yg mempengaruhi harga saham. Aspek-aspek internal yg digunakan dalam eksperimen ini adalh ROA, ROE, NIM dan BOPO. Pada keempat variable ini merupaakan variable yg paling umum diigunakan oleh investor untuk menilai tiingkat profitabilitas pada sektor perbankan (Harahap \& Hairunnisah, 2017).

Return On Assets (ROA) merupaakan bagian dari rasio keuangan profitabilitas, ROA digunakan sebagai pengukur kemampuan manajemen $\mathrm{dlm}$ mmperoleh margin atau laba dalam mengontrol perseoran. Semakin besar niali ROA, maka semaakin biak dalam memberikan return kepada investor dan secara tak langsung akan meningktkan permntaan trhadap harga saham pada persaahaan terkait (Harahap \& Hairunnisah, 2017).

Return On Equity (ROE) mewujudkan rasio yg menunjukan sjauh mana kemampuan peruashaan dalam mengahasilkan keuntungan atau laba ynag bisa dperoleh oleh invstor. Jika ROE yg dihasilkan terus melambung maka seammkin tingggi jg return yg diperoleh, ROE yg terus melambung akan menimbulkan daya tarik para investor terhadap perseoran (Tandelilin, 2007). 
Net Interest Margin (NIM) adalh rsaio yg digunakan untuk menilai kemahiran manajer dalam pengelolaan akiva produktif sehingga sanggup mengghasilkan bunga bersih. Semakin tinggi rasio NIM, yg berarti semakin tinggi profitabilitas bank, hal ini secara tak langsung akan meninngkatkan harga saham (Indriani et al., 2019)

Biaya Operasional/Pensanggupan Operasional (BOPO) atau sanggup diesbut rasio efiisiensi, dalam mnegukur kemampuan manajer institusi keuangan untuk mengendaliikan biaya operasional trhadap pensanggupan opearsional sanggup menggunakan rasio BOPO. Rasio ini diperoleh dari membnadingkan antara total biaya operasional trhadap total pensanggupan operasional bank. Semakin rendah rasio BOPO maka semakin efisien bank dalam menjalankan operasionalnya, begitu pula sebaliknya. Profitabilitas bank akn berkembang jika manajemen bank sanggup mengefisiensikan biaya operasional trhadap pensanggupan operasionalnya, dan pada akhirnya return yg diperoleh oleh investor akan meningkat. Oleh sebab itu, besar kecilnya persentase suatu BOPO langsung mempengaruhi keuntungan atau laba dan akan mempengaruhi harga saham pada perseoran perbankan itu (Jogiyanto, 2008).

Kinerja dan kesehatan bank merupaakan suatu faktor yg dilihat terlebih dahulu oleh investor sebelum menginvestasikan dananya ke perseoran perbankan. Perseoran perbankan yg mmiliki kinerja dan kesehatan yg biak diharapkan akan memiiliki keuntungan atau laba yg sanggup dinikmati oleh investor, sehingga pada akhirnya perseoran trsebut akan dipercaya oleh investor dikarena memliki nama baik yg baik dan akhirnya sanggup mengingkatkan harga saham (Harahap \& Hairunnisah, 2017).

Pada riset (Patar, Andrew, 2014) menunjukan bahwa ROA berpengaruh singifikan trhadap harga saham pada perseoran yg masuk di indeks LQ45. Hal ini juga senada dengan riset (Manoppo, 2015) dan riset (Wardana et al., 2017) yg membuktikan bahwa ROA berpengaruh signifikan trhadap harga saham. Dengan hal trsebut hipotesis yg diajukan:

\section{$\mathbf{H}_{1}$ : Return on Asset Berpengaruh Positif Terhadap Harga Saham.}

Riset (Manoppo, 2015) membuktikkan bahwa ROE sangat berpengaruh trhadap harga saham. Ini karena ROE adalh rasio yg penting dan jika nilainya tinggi dan terus stabil akan membuat harga saham naik. Hal ini juga ditunjukkan oleh riset (Wardana et al., 2017) dan riset (Ratih, 2013) dimana hasil riset menyebutkan bahwa ROE berpengaruh positif dan signifikan trhadap Harga Saham Hasil berbeda ditunjukkan pada riset Harahap, dkk (2017) bahwa ROE tak berpengaruh signifikan trhadap harga saham. Dengan hal ini hipotesis yg diajukan:

\section{$\mathrm{H}_{2}$ : Return On Equity Berpengaruh Positif Terhadap Harga Saham.}

Riset yg dilakukan oleh (Wismaryanto, 2013) dan (Harahap \& Hairunnisah, 2017) menunjukan bahwa NIM berpengaruh positif dan signifikan trhadap harga saham. Dengan hal ini hipotesis yg diajukan:

\section{$\mathbf{H}_{3}$ : Net Interest Margin Berpengaruh Positif Terhadap Harga Saham.}

Hasil riset (Wismaryanto, 2013) dan (Prasetyo, 2016) menunjukan bahwa BOPO memiliki pengaruh secara signifikan trhadap harga saham. Denggan hal ini hipotesis yg diajukan:

\section{$\mathrm{H}_{4}$ : BOPO Berpengaruh Positif Terhadap Harga Saham.}

Riset (Sukamto, 2016) menunjukan bahwa inflasi berpengaruh positif trhadap variable dependen yaitu Indeks Harga Saham Gabungan. Senada dengan kedua riset di atas, riset (Ulandari, 2017) menyebutkan bahwa inflasi berpengaruh positif dan singnifikan trhadap harga saham di sektor industri barang konsumsi pada (ISSI). Dengan hal ini hipotesis yg diajukan:

\section{$\mathrm{H}_{5}$ : Tingkat Inflasi Berpengaruh Positif Terhadap Harga Saham.}

Riset (Lutfiana, 2017)membuktikan bahwa BI Rate berpengaruh positif dan tak signifikan trhadap harga saham Kelompok Jakarta Islamic Index di Indonesia periode 2007- 
2015. Pada riset (Lutfiana, 2017)menunjukan bahwa BI Rate berpengaruh positif dan tak signifikan terhadap harga saham. Senada dengan hasil riset (Afiyanti, 2017) dan (Rohmanda, 2014) menyatakan bahwa BI Rate berpengaruh positif dan signifikan trhadap harga saham. Dengan hal ini hipotesis yg diajukan:

\section{$\mathrm{H}_{6}$ : BI Rate Berpengaruh Positif Terhadap Saham.}

Berdasarkan riset (Wismaryanto, 2013) mennjukkan bahwa variable NPL, LDE, ROA, ROE, NIM BOPO dan CAR secara simultan memiliki hibungan yang singnifikan trhadap harga saham. Dengan hal ini hipotesis yg diajukan:

\section{$\mathrm{H}_{7}$ : ROA, ROE, NIM, BOPO, Tingkat Inflasi Dan BI Rate Secara Simultan Berpengaruh Positif Terhadap Harga Saham.}

\section{Metode}

Pada riset ini, yg menjadi populasi riset adalah perseoran-perseoran pada sub sektor perbankan yg sudah listing di Bursa Efek Indonesia (BEI). Dalil dalam memilih perseoran sub sektor perbankan dalam riset ini yaitu perbankan memrupakan salah satu sektor yg dihaarpkan memiliki peluan yang cerah di masa yang akan datang, karena saat ini aktivitas masyaarakat Indonesia tak lepas dari jasa perbankan dan perseoran perbankan merupaakan perseoran yg mmpunyai kontribusi yg cukup besar trhadap pensanggupan negara. Jumlah perseoran sub sektor perbankan yg menjadi populasi sebanyak 43 perseoran.

Pada riset ini menggunakan purposive sampling yg merupaakan salah satu dari teknik pengambilan sample yg dilakukan berdasarkan kriteria atau pertimbangan yg khusus. Peneliti menentukan kriteria sample sebagai berikut:

a. Perseoran pada sektor finance sub sektor perbankan yg menerbitkan LK Tahunan pada periode periode 2015-2019.

b. Perseoran memiliki data hrga penutupan saham akhir tahun dimana data trsebut diinformasikan pada LK Tahunan, serta saham trsebut aktif dijualbelikan selama periode 2015-2019

c. Perseoran memiliki data yg menggunakan mata uang Rupiah (Rp) dimana data trsebut diinformasikan pada LK Tahunan.

d. Perseoran sub sektor perbankan yg memiliki data informasi ROA, ROE, NIM, BOPO yg diperlukan secara lengkap pada LK Tahunan periode 2015-2019

Berdasarkan kriterian di atas, bersumber dari website Bursa Efek Indonesia sample yg bisa digunakan sebanyak 32 perseoran sub sektor Perbankan selama periode 2015-2019.

Dalam memperoleh data, maka dilakukan pengumpulan data terlebih dahulu. Teknik rangkaian data yg digunakan dalam riset ini menggunakan teknik documentation. Dalam pencatatan dokumen dilakukan dengan menelusuri data harga saham dan data LK tahunan yg diakses dari website Bursa Efek Indonesia (BEI) dan/atau pada website perseoran terkait.

\section{Hasil dan Pembahasan}

Statistik deskriptif adalah perangkaan yang digunakan untuk menganalisis data dengan cara mendeskripsikan atau menggambarkan data yang dikumpulkan sebagaimana adanya tanpa bertujuan menarik kesimpulan yang bersifat menyamaratakan. Hasil riset analisis statistic deskriptif sanggup dilihat dalam table dibawah ini:

\section{Tabel 1. Hasil Analisis Deskriptif}

\begin{tabular}{lccccc}
\hline & $\mathrm{N}$ & Minimum & Maximum & Mean & Std. Deviation \\
\hline ROA & 160 & $-4,90$ & 4,19 & 1,53 & 1,28 \\
ROE & 160 & $-38,30$ & 29,89 & 8,61 & 8,03 \\
NIM & 160 & 0,68 & 15,82 & 5,90 & 2,58 \\
BOPO & 160 & 3,89 & 150,80 & 84,38 & 13,98 \\
Inflasi & 160 & 3,03 & 6,38 & 3,99 & 1,23 \\
BI Rate & 160 & 4,56 & 7,52 & 5,80 & 1,01 \\
Harga Saham & 160 & 71,00 & $29.933,00$ & $2.096,24$ & $3.886,20$ \\
\hline Valid N (listwise) & 160 & & & & \\
\hline
\end{tabular}


Uji asumsi klasik digunakan untuk mendeteksi ada atau tidaknya penyimpangan asumsi klasik atau persamaan regresi berganda yang digunakan. Penguji asumsi ini terdiri atas uji normalitas, multikolinearitas, heteroskedastisitas, dan autokorelasi (Sugiyono, 2017). Hasil riset uji asumsi klasik dapat dilihat pada table di bawah ini.

Tabel 2. Hasil Uji Asumsi Klasik

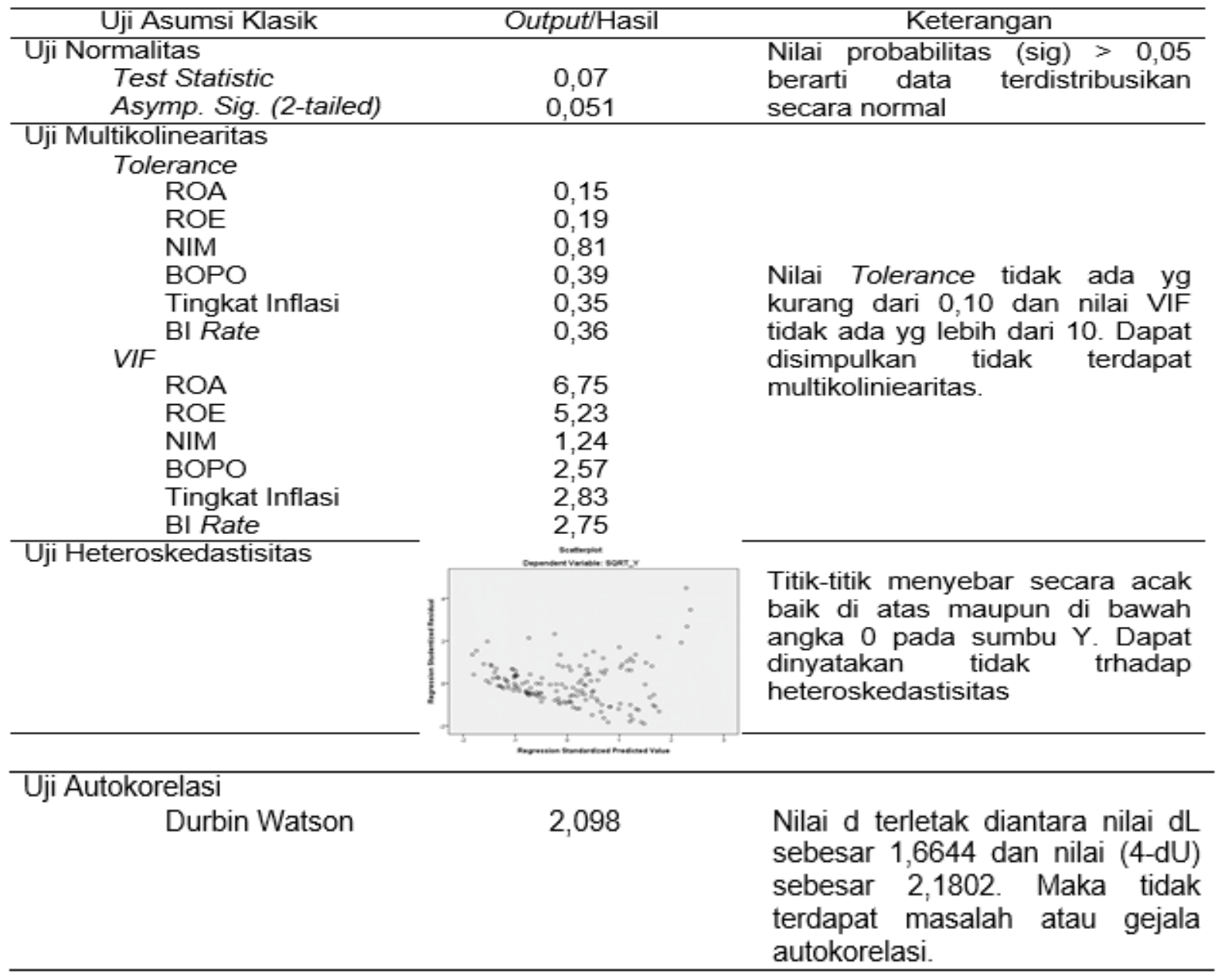

Nilai coefficient of determination diperoleh dari nilai Adjusted $R$ Square yaitu sebesar 0,28 atau jika di presentasekan sebesar $28 \%$. Hal ini sanggup diartikan bahwa variable ROA, ROE, NIM, BOPO, Tingkat Inflasi dan BI Rate berpengaruh secara simultan trhadap Harga Saham $(Y)$ sebesar $28 \%$, sedangkan sisanya sebesar $72 \%$ dipengaruhi oleh variable lain di luar persamaan regresi.

Untuk sanggup mengetahui pengaruh ROA, ROE, NIM, BOPO, Tingkat Inflasi dan BI Rate trhadap Harga Saham (Y), maka dibuatkan Analisis Regresi Linear Berganda. Hasil riset Analisis Regresi Linear Berganda sanggup amati pada table 3 di bawah ini:

Tabel 3. Hasil Analisis Regresi Linier Berganda

\begin{tabular}{lccc}
\hline \multicolumn{1}{c}{ Model } & $\begin{array}{c}\text { Unstandardized } \\
\text { Coefficients } B\end{array}$ & $t$ & sig \\
\hline Constant & $9.159,58$ & 1,70 & 0,09 \\
ROA & $1.691,28$ & 2,73 & 0,01 \\
ROE & $-152,31$ & $-2,06$ & 0,04 \\
NIM & $-136,92$ & $-1,18$ & 0,24 \\
BOPO & $-90,42$ & $-1,73$ & 0,09 \\
Tingkat Inflasi & $-382,24$ & $-1,07$ & 0,29 \\
BI Rate & 290,23 & 0,68 & 0,50 \\
\hline
\end{tabular}


Pada table 3 di atas, konstantan sebesar 9.159,58 artinya apabila sebelum atau tanpa adanya ROA, ROE, NIM, BOPO, tingkat inflasi dan BI Rate maka harga saham sebesar Rp 9/159.58. Koefisien ROA sebesar 1.691,28 menunjukkan bahwa setiap penambahan ariabel $\mathrm{X}_{1}$ sebesar $1 \%$ maka harga saham akan mengalami kenaikan sebesar Rp 1.691,28. Koefisien ROE sebesar $-152,31$ menunjukkan bahwa setiap penambahan variable $\mathrm{X}_{2}$ sebesar $1 \%$ maka harga saham akan mengalami penurunan sebesar Rp 152,31. Koefisien NIM sebesar -136,92 menunjukkan bahwa setiap penambahan variable $\mathrm{X}_{3}$ sebesar $1 \%$ maka harga saham akan mengalami penurunan sebesar $\mathrm{Rp} 136,92$. Koefisien BOPO sebesar -90,42 menunjukkan bahwa setiap penambahan variable $\mathrm{X}_{4}$ sebesar $1 \%$ maka harga saham akan mengalami penurunan sebesar Rp 90,42. Koefisien Tingkat Inflasi sebesar $-382,24$ menunjukkan bahwa setiap penambahan variable $X_{5}$ sebesar $1 \%$ maka harga saham aka menalami penurunan sebesar $\mathrm{Rp} 328,24$. Koefisien $\mathrm{BI}$ Rate sebesar 290,23 menunjukkan bahwa setiap penambahan variable $X_{5}$ sebesar $1 \%$ maka harga saham akan mengalami kenaikan sebesar RP 290,23.

\section{Pengaruh Reurn on Assets Terhadap Harga Saham}

Pada hasil uji t menunjukan nilai signifikansi Return On Assets sebesar 0,01<0,05 maka sanggup dinyatakan bahwa ROA berpengaruh trhadap harga saham. Nilai t positif menunjukan bahwa variable $X_{1}$ mmpunyai hubungan yg searah dengan $Y$. Jadi sanggup disimpulkan bahwa $\mathrm{H}_{1}$ sanggup diterima yaitu Return On Asset berpengaruh positif dan signifikan trhadap harga saham.

Pada hasil pengujian yg dilakukan disimpulkan bahwa ROA memiliki pengaruh positif dan signifikan trhadap harga saham, hal ini sejalan dengan riset (Patar, Andrew, 2014) dan (Manoppo, 2015) yg menunjukan bahwa ROA berpengaruh signifikan trhadap harga saham.

\section{Pengaruh Return on Equity Terhadap Harga Saham}

Padahasil uji t menunjukkan nilai signifikan Ruturn On Equity sebesar $0,40<0,05$, maka sanggup dinyatakan bahwa ROE berpengaruh terhadap harga saham. Nilai t negative menunjukkan bahwa variable $X_{2}$ mempunyai hubungan yang tak searah dengan $Y$. Jadi sanggup disimpulkan bahwa $\mathrm{H}_{2}$ sanggup diterima yait Return On Asset berpengaruh negative dan sginifikan terhadap harga saham.

\section{Pengaruh Net Interest Margin Terhadap Harga Saham}

Pada hasil uji t menunjukkan nilai signifikan Net Interest Margin sebesar 0,24>0,05 maka sanggup dinyatakan bahwa NIM tak berpengaruh terhadap harga sahm. NIlai $t$ negative menunjukkan bahwa variable $\mathrm{X}_{3}$ mempunyai hubungan yang tak searah dengan $\mathrm{Y}$. Jadi sanggup disimpulkan bahwa H3 ditolak yaitu Net Interest Margin berpengaruh negative dan tak signifikan terhadap harga saham.

\section{Pengaruh BOPO Terhadap Harga Saham}

Hasil uji t menunjukan nilai singnifikansi BOPO sebesar 0,09>0,05 maka sanggup dinyatakan bahwa BOPO tak berpengaruh trhadap harga saham. Nilai t negatif menunjukan bahwa variable $\mathrm{X}_{4}$ mempunyai hubungan yang tak searah dengan $\mathrm{Y}$. Jadi sanggup disimulkan bahwa $\mathrm{H}_{4}$ ditolak yaitu BOPO berpengaruh negative dan tak signifikan terhadap harga saham.

Disanggupkan bahwa BOPO tak berpengaruh trhadap harga saham. Hal ini sejalan dengan hasil riset dari (Harahap \& Hairunnisah, 2017) yg menyatakan bahwa tak tersanggup pengaruh yg signifikan antara BOPO trhadap harga saham. Rasio BOPO tak berpengaruh terhadap harga saham dikarenakan kemampuan perseoran dalam memeperoleh laba dan kemampuan dalam mengendalikan semua biaya-biaya operasional perseoran dan non operasional perseoran sangatlah rendah, sehingga BOPO kurang berpengaruh trhadap harga saham. Jadi pada rasio ini, signaling theory tak sanggup memberikan sinyal trhadap para investor. 


\section{Pengaruh Tingkat Inflasi Terhadap Harga Saham}

Pada hasil uji t menunjukan nilai singnifikansi variable Inflasi sebesar 0,29>0,05 maka sanggup dinyatakan bahwa Inflasi tak berpengaruh trhadap harga saham. Nilai t negatif menunjukan bahwa variable $X_{5}$ mmpunyai hubungan yg tak searah dengan $Y$. Jadi sanggup disimpulkan bahwa $\mathrm{H}_{5}$ ditolak yaitu Inflasi berpengaruh negatif dan tak signifikan trhadap harga saham.

Disimpulkan Inflasi berpengaruh negatif dan tak signifikan trhadap harga saham. Sehingga signaling theory dari tingkat inflasi trhadap harga saham tak sanggup memberikan sebuah sinyal, sebaliknya jika tingkat inflasi di atas $10 \%$ sanggup memberikan sebuah sinyal kepada para investor, dan secara tak langsung akan berimbas ke harga saham.

\section{Pengaruh BI Rate Terhadap Harga Saham}

Pada hasil uji t menunjukan nilai singnifikansi variable $\mathrm{BI}$ Rate sebesar $0,50>0,05$ maka sanggup dinyatakan bahwa BI Rate tak berpengaruh trhadap harga saham. Jadi, disimpulkan bahwa $\mathrm{H}_{5}$ ditolak yaitu $\mathrm{BI}$ Rate berpengaruh positif dan tak signifikan trhadap harga saham.

Pengaruh ROA, ROE, NIM<BOPO, Tingkat Inflasi dan BI Rate Secara Simultan Terhadap Harga Saham

Pengujuan regresi secara simultan dilakukan untuk sanggup menunjukan semua variable yg diguankan dalam model regresi memiliki pengaruh yg singnifikan trhadap variable Y. Berikut hasil Simultan diliihat pada tabel dibawah ini:

Tabel 4. Hasil Uji Simultan

\begin{tabular}{lcccc}
\hline \multicolumn{1}{c}{ Model } & $d f$ & Mean Square & $F$ & Sig \\
\hline Regression & 6 & $124.361 .235,99$ & 11,50 & 0,00 \\
Residual & 153 & $10.817 .888,83$ & & \\
Total & 159 & & & \\
\hline
\end{tabular}

Berdasarkan pada pengujian uji $\mathrm{F}$ diatas dapat dilihat bahwa nilai probabilitas (Sig.) sebesar $0,00<0,05$. Nilai 0,05 lebih besar daripada nilai probabilitas, maka dapat disimpulkan variable $\mathrm{ROA}\left(\mathrm{X}_{1}\right)$, $\mathrm{ROE}\left(\mathrm{X}_{2}\right)$, NIM $\left(\mathrm{X}_{3}\right)$, BOPO $\left(\mathrm{X}_{4}\right)$, Inflasi $\left(\mathrm{X}_{5}\right)$, dan BI Rate $\left(\mathrm{X}_{6}\right)$ secara simultan berpengaruh secara signifikan terhadap Harga Saham (Y).

Signaling Theory dapat memberikan sebuah sinyal kepada investor yang disajikan dalam LK perseroan dan pada informasi makro ekonomi yang diterbitkan oleh pemerintah. Sehingga ROA, ROE, NIM, BOPO, tingkat inflasi dan I Rate bersama-sama dapat memberikan sebuah sinyal yang positif terhadap investor. Hal ini sejalan dengan riset (Wismaryanto, 2013) yang menunjukkan bahwa adanya pengaruh yang signifikan variable NPL, LDR, ROA, ROE, NIM, BOPO, dan CAR secara simultan. Kemudian sejalan dengan hasil riset (Patar, Andrew, 2014) menyebutkan bahwa factor internal dan factor eksternal berpengaruh signifikan terhadap pergerakan harga saham.

\section{Simpulan dan Saran}

Berdasarkan hasil penelitian yang telah dibahsa sebelumnya dapat disimpulkan bahwa (1) Secara parsial variable Return On Assets memiliki skala sigifikansi sebesar $0,01<0,05$ maka bisa dinyatakan bahwa $X_{1}$ mmpunyai pengaruh trhadap $Y$. Skala t positif menunjukan bahwa variable $X_{1}$ mmpunyai relasi yg sehadap dengan $Y$. Jadi,disimpulkan bahwa $\mathrm{H}_{1}$ diterima yaitu $\mathrm{ROA}$ berpengaruh secara positif dan signifikan trhadap harga saham. (2) Secara parsial variable Net Interest Margin memiliki skala sigifikansi sebesar $0,24>0,05$ maka bisa dinyatakan bahwa variable $X_{3}$ tak mmpunyai pengaruh trhadap $Y$. Skala t negatif menunjukan bahwa variable $X_{3}$ mmpunyai relasi yg tak sehadap dengan $Y$. Jadi bisa disimpulkan bahwa $\mathrm{H}_{3}$ ditolak berarti NIM berpengaruh negatif dan tak signifikan trhadap harga saham. (3) Secara persial variable Return On Equity memiliki skala signifikan sebesar $0,04<0,05$ maka bisa dinyatakan bahwa variable $X 2$ mempuyai pengaruh terhadap $\mathrm{Y}$. Skala t negative menunjukkan bahwa variable $\mathrm{X} 2$ mempunyai relasi yang tak sehadap 
dengan Y. Jadi bisa disimppulkan bahwa H2 diterima yaitu ROE berpengaruh signifikan terhadap harga saham. (4) Secara parsial variable BOPO memiliki skala sigifikansi sebesar $0,09>0,05$ maka bisa dinyatakan bahwa variable $\mathrm{X}_{4}$ tak mmpunyai pengaruh trhadap $\mathrm{Y}$. Skala t negatif menunjukan bahwa variable $\mathrm{X}_{4}$ mmpunyai relasi yg tak sehadap dengan $\mathrm{Y}$. Jadi bisa disimpulkan bahwa $\mathrm{H}_{4}$ ditolak berarti BOPO berpengaruh negatif dan tak signifikan trhadap harga saham. (5) Secara parsial variable Tingkat Inflasi memiliki skala sigifikansi sebesar 0,29>0,05 maka bisa dinyatakan bahwa variable $X_{5}$ mmpunyai pengaruh trhadap $Y$. Skala t negatif menunjukan bahwa variable $X_{5}$ mmpunyai relasi yg tak sehadap dengan $Y$. Jadi bisa disimpulkan bahwa $\mathrm{H}_{5}$ ditolak berarti Tingkat Inflasi berpengaruh negatif dan tak signifikan trhadap harga saham. (6) Secara parsial variable BI Rate memiliki skala singifikansi sebesar $0,50>0,05$ maka bisa dinyatakan bahwa variable $X_{6}$ tak mmpunyai pengaruh trhadap $Y$. Skala $t$ positif menunjukan bahwa variable $X_{2}$ mmpunyai relasi yg sehadap dengan $\mathrm{Y}$. Jadi bisa disimpulkan bahwa $\mathrm{H}_{6}$ ditolak berarti $\mathrm{BI}$ Rate tak berpengaruh signifikan trhadap harga saham. (7) Secara simultan variable ROA, ROE, NIM, BOPO, Tingkat Inflasi, dan BI Rate memiliki skala singifikansi sebesar $0,00<0,05$. Jadi bisa disimpulkan bahwa $\mathrm{H}_{7}$ diterima yaitu variable $\mathrm{ROA}$, ROE, NIM, BOPO, Tingkat Inflasi, dan BI Rate secara simultan berpengaruh secara signifikan trhadap Harga Saham (Y).

\section{Daftar Rujukan}

Afiyanti, H. T. (2017). Pengaruh Inflasi, BI Rate dan Nilai Tukar Terhadap Return Saham (Studi Pada Perusahaan Subsektor Food \& Beverages Yang Terdaftar Di Bursa Efek Indonesia Periode 2013-2016). Jurnal Administrasi Bisnis, Vol. 61 No.2.

Alwi, I. Z. (2003). Pasar Modal: Teori dan Aplikasi, panduan praktis. Jakarta : Nasindo.

Harahap, D. A., \& Hairunnisah, A. I. (2017). Pengaruh NPL, LDR, GCG, NIM, ROA, ROE, CAR, BOPO Terhadap Harga Saham Pada Perusahaan Perbankan yang Terdaftar di Bursa Efek Indonesia dari Tahun 2010-2014. Jurnal Dimensi.

Indriani, M., Yulia, A., Nadirsyah, N., \& Ariska, L. P. (2019). Whistleblowing Intention, Personal Cost, Organizational Commitment and Fraud Seriousness Level. Journal of Accounting and Investment. https://doi.org/10.18196/jai.2002121

Jogiyanto. (2008). Teori Portofolio dan analisis Investasi Edisi kelima. Yogyakarta : BPFE.

Kasmir. (2012). Analisis Laporan Keuangan. Jakarta : Raja Grafindo.

Kewal, S. S. (2013). Pengaruh Inflasi, Suku Bunga, Kurs dan Pertumbugan PDB Terhadap Indeks Harga Saham Gabungan. Jurnal Economia, Vol. 8, No.1.

Lutfiana, I. M. (2017). Kontribusi Inflasi, Suku Bunga, Kurs, Produk Domestik Bruto Terhadap Harga Saham Kelompok Jakarta Islamic Index Di Indonesia Periode 2007-2015. AnNisbah: Jurnal Ekonomi Syariah, Vol. 4 No.1 https://doi.org/10.21274/an.2017.4.1.75104

Manoppo, C. P. (2015). The Influence of ROA, ROE, ROS, and EPS on Stock Price. Jurnal EMBA, Vol. 3, No,4. Hal 691-697.

Patar, Andrew, dkk. (2014). Faktor Internal dan Eksternal yg Mempengaruhi Pergerakan Harga Saham. Jurnal Administrasi Bisnis, Vol. 11, N.1.

Prasetyo, S. (2016). Pengaruh Non Performing Loan, Loan To Deposit Ratio, Return On Assets, Net Interest Margin, Beban Operasional Pada Pensanggupan Operasional, Capital Adequacy Ratio Trhadap Harga Saham Perbankan Yg Terdaftar Di Bursa Efek Indonesia (Periode 2011-2015). Universitas STIKUBANK. 
Ratih, dkk. (2013). Pengaruh EPS, PER, DER, ROE Trhadap Harga Saham Pada Perseoran Sektor Pertambangan Yg Terdaftar di Bursa Efek Indonesia (BEI) Tahun 2010-2012. Diponegoro Journal Of Social and Politic, Hal 1-12.

Rohmanda, D. (2014). Pengaruh Kurs Rupiah, Inflasi Dan Bi Rate Terhadap Harga Saham (Studi pada Indeks Sektoral Bursa Efek Indonesia Periode 2005-2013). Jurnal Administrasi Bisnis S1 Universitas Brawijaya, Vol. 13, N.1

Sugiyono. (2017). Metode Penelitian Kuantitatif Kualitataif dan R\&D. Bandung : CV Alfabeta.

Sujarweni, V. W. (2017). Analisis LK: Teori, Aplikasi, \& Hasil Riset. Yogyakarta : Pustaka baru Press.

Sukamto, S. W. (2016). Pengaruh Inflasi, Suku Bunga, dan Nilai Tukar Rupiah Terhadap Indeks HargaSaham Gabungan (IHSG) di Bursa Efek Indonesia. Jurnal Manajemen Bisnis, Vol.6, No. https://doi.org/https://doi.org/10.1017/CBO9781107415324.004

Tandelilin, E. (2007). Analisis Investasi dan Manajemen (Edisi Pertama, Cetakan kedua). Yogyakarta ; BPFE.

Ulandari, S. (2017). , riset Ulandari (2017) menyebutkan bahwa inflasi berpengaruh positif dan singnifikan trhadap harga saham di sektor industri barang konsumsi pada (ISSI) [UIN Raden Fatah Palembang]. https://doi.org/http://eprints.radenfatah.ac.id/1011/1/SKRIPSI\%20SUSI\%20ULANDARI \%20\%2813190276\%29.pdf

Wardana, I. G. A. K., Sujana, E., \& Wahyuni, M. A. (2017). Pengaruh Pengendalian Internal, Whistleblowing System Dan Moralitas Aparat Terhadap Pencegahan Fraud Pada Dinas Pekerjaan Umum Kabupaten Buleleng. E-Journal S1 Ak Universitas Pendidikan Ganesha.

Website Bank Indonesia. (n.d.). . http://bi.go.id

Wismaryanto, S. D. (2013). Pengaruh NPL, LDR, ROA, ROE, NIM, BOPO, dan CAR Trhadap Harga Saham Pada Sub Sektor Perbankan Yg Terdaftar di Bursa Efek Indonesia Tahun 2008-2012. Jurnal Manajemen, Vol. 3, No.1. 